\title{
ANALISIS TINGKAT PEMAHAMAN KPR SYARIAH PADA BANK SYARIAH DI INDONESIA: STUDI PENDAHULUAN
}

\author{
Mohamad Heykal \\ Accounting and Finance Department, Faculty of Economic and Communication, BINUS University \\ Jln. K.H. Syahdan No. 9, Palmerah, Jakarta Barat 11480 \\ mheykal@binus.edu
}

\begin{abstract}
Sharia banking has been growing in many countries since the birth of post-neo revivalist movement in the mid-20th century. The development of Indonesian sharia banking began with a workshop related with interests and banking held by MUI in Cisarua on 18th to 20th of August 1990. Since 1992 to 2013 it has been established 11 sharia commercial banks and 24 sharia conventional banks that open sharia business units and 156 Islamic Financing Bank. In terms of existing office, Islamic banks in Indonesia have reached 1737 bank offices and also Islamic bank units. Moreover, the market share of Islamic banking has almost reached $5 \%$ of the total market share banking in Indonesia. Islamic banking also has a mortgage product that is essentially different from the existing mortgage in the conventional banking. It is expected that the Islamic mortgage product will result a profit. The product is a product released for customers who require financing from Islamic bank to have a house. This early study used literature review method and secondary data. This study built an analysis of the mortgage program issued by Islamic banks in Indonesia. Research concludes that the notion of Islamic banking on mortgage product, especially Islamic financing mortgage, from the internal party has not well distributed yet.
\end{abstract}

Keywords: sharia, Islamic banking, mortgage, Islamic home financing

\begin{abstract}
ABSTRAK
Perbankan syariah mulai berkembang di banyak negara pasca-lahirnya gerakan neo revivalis pada pertengahan abad ke-20. Di Indonesia sejarah perkembangan perbankan syariah diawali dengan diadakannya lokakarya berkaitan dengan bunga bank dan perbankan yang dilakukan MUI di kawasan Cisarua pada 18 hingga 20 Agustus 1990. Semenjak 1992 hingga 2013 telah berdiri 11 bank umum syariah dan 24 bank konvensional yang membuka unit usaha syariah serta 156 Bank Pembiayaan Syariah. Dari segi jumlah kantor, bank syariah yang ada saat ini di Indonesia telah mencapai 1737 kantor bank umum syariah dan unit usaha syariah. Ditambah lagi, pangsa pasar perbankan syariah telah hampir mencapai 5\% dari total pangsa pasar perbankan di Indonesia. Perbankan syariah juga memiliki produk KPR yang pada dasarnya berbeda dengan $K P R$ yang ada di perbankan konvensional. Produk KPR syariah diharapkan untuk memperoleh keuntungan. Produk ini merupakan produk yang dikeluarkan bagi nasabah yang memerlukan pembiayaan dari bank syariah untuk mendapatkan rumah. Penelitian awal dengan menggunakan metode studi literatur dan data sekunder ini berusaha untuk membuat suatu analisis mengenai program KPR syariah yang dikeluarkan oleh perbankan syariah di tanah air. Dari hasil penelitian diperoleh bahwa pemahaman pihak internal bank syariah tentang produk bank syariah terutama KPR syariah masih belum merata.
\end{abstract}

Kata kunci: syariah, perbankan syariah, KPR syariah 


\section{PENDAHULUAN}

Bagi masyarakat Indonesia rumah merupakan cerminan dari pribadi manusianya, baik itu secara perorangan maupun dalam suatu kesatuan dan kebersamaan dengan lingkungan alamnya. Permasalahan perumahan dan permukiman merupakan sebuah isu utama yang selalu mendapat perhatian lebih dari pemerintah. Hal tersebut menjadi isu utama yang selalu menjadi primadona dari dulu hingga sekarang. Permasalahan perumahan dan permukiman merupakan sebuah permasalahan yang berlanjut dan bahkan akan terus meningkat, seirama dengan pertumbuhan penduduk, dinamika kependudukan, dan tuntutan-tuntutan sosial ekonomi yang makin berkembang. Keinginan memiliki rumah merupakan keinginan masyarakat. Dengan adanya rumah, maka anggota keluarga dapat terlindungi dan juga dapat berkomunikasi. Meskipun begitu, usaha untuk mendapatkan rumah saat ini bukan hal yang mudah. Jumlah lahan yang makin terbatas membuat harga rumah menjadi makin mahal, tidak mungkin terjangkau banyak kalangan masyarakat dengan pendapatan rata-rata pada batas upah minimum regional atau di bawah upah minimum regional. Karena itu, usaha untuk mendapatkan rumah saat ini tidak hanya dilakukan secara tunai, tetapi juga dengan kegiatan pembiayaan. Maka dari itu lahir kredit pemilikan rumah yang dilakukan oleh dunia perbankan. KPR merupakan salah satu jenis layanan yang diberikan bank kepada para nasabah yang berharap mendapatkan pelayanan untuk mendapatkan pinjaman dalam pemberian kredit perumahan. KPR muncul karena adanya kebutuhan yang tinggi di kalangan masyarakat untuk dapat memiliki rumah tanpa diimbangi dengan peningkatan daya beli di masyarakat. KPR sendiri pada awalnya merupakan salah satu produk yang dikeluarkan oleh bank konvensional. Akan tetapi, seiring dengan perkembangannya, juga banyak dilakukan oleh perbankan syariah.

KPR merupakan salah satu jenis layanan yang diberikan oleh bank kepada para nasabah yang berharap mendapatkan pelayanan untuk mendapatkan pinjaman dalam pemberian kredit perumahan kepada nasabahnya. KPR muncul karena adanya kebutuhan yang tinggi di kalangan masyarakat untuk dapat memiliki rumah tanpa diimbangi dengan peningkatan daya beli di masyarakat. Produk KPR yang ada pada perbankan syariah pada dasarnya berbeda dengan KPR yang ada di perbankan konvensional. Perbedaan ini dapat terjadi karena terdapat perbedaan prinsip antara perbankan syariah dengan perbankan konvensional. Dalam perbankan syariah biasa dikenal konsep berbasis bagi hasil dan juga perdagangan. Sedangkan dalam perbankan konvensional, dikenal sistem yang berbasis bunga. Dalam produk yang biasa dikenal dengan nama KPR syariah ini terdapat beberapa karakteristik yang berbeda. Di antaranya adalah pemberlakuan sistem kredit yang ada pada perbankan konvensional sementara pada perbankan syariah konsep KPR syariah menggunakan beberapa akad yaitu murabaha, ijarah muntahiya bittamlik, dan juga musyarakah mutanaqisah. Yang menjadi masalah adalah bahwa banyak masyarakat yang mengangggap bahwa produk KPR yang dikeluarkan oleh bank syariah merupakan produk yang tidak berbeda dengan yang dikeluarkan oleh bank konvensional. Hasil riset yang dilakukan oleh Alwi (2011) menunjukkan bahwa pemasaran produuk yang dikeluarkan oleh bank syariah, khususnya KPR sering kali mendapatkan tantangan dengan fakta bahwa pemahaman masyarakat masih sering terganggu dengan bank konvensional. Apalagi fakta menunjukkan bahwa masyarakat lebih banyak mengenal bank konvensional dibandingkan dengan bank syariah.

\section{Tinjauan Pustaka}

Terdapat beberapa penelitian yang berbicara tentang konsep pembiayaan perumahan secara syariah atau KPR Syariah. Rosyida (2013) menyatakan bahwa bagi masyarakat yang memiliki kemampuan dalam keuangan, membeli sebuah rumah secara tunai bukanlah sebuah kendala. Namun bagi masyarakat yang memiliki keterbatasan dalam keuangan, membeli rumah secara tunai menjadi sebuah kendala. Sehingga banyak masyarakat yang memilih membeli rumah secara kredit. Hal ini disebabkan pembayaran secara kredit dianggap lebih ringan dibandingkan pembayaran secara tunai. 
Banyaknya kebutuhan masyarakat akan kredit rumah membuat bank mengeluarkan produk-produk pembiayaan, seperti Kredit Pemilikan Rumah (KPR).

Selain itu Thomas menyatakan bahwa komunitas Islam negeri di Amerika Serikat makin menunjukkan kedalaman jumlahnya. Tidak seperti masyarakat baru lain, Muslim berusaha untuk mengatur urusan mereka sesuai dengan aturan Syariah. Populasi muda dan makmur ini telah makin diselidiki berarti untuk menerapkan konsep-konsep Islam untuk kehidupan finansial mereka, termasuk akuisisi rumah meskipun hanya sekarang vendor muncul yang berusaha untuk memenuhi kebutuhan. Badan layanan seperti itu masih mencari alat terbaik untuk menerapkan bagaimana menggunakan aplikasi tersebut dalam proses real estate yang ada. Sebelum 1997, tidak adanya dukungan regulasi perbankan berarti bahwa semua upaya AS untuk menyediakan pembiayaan rumah syariah. Untuk tingkat yang lebih rendah mereka memiliki terbatas integrasi baik Syariah, beasiswa, dan pasar modal Islam internasional. Interpretasi peraturan perintis diperoleh Bank Serikat Kuwait (UBK) telah mulai membuka kedua pintu untuk keuangan Islam di Amerika, pengembangan sekuritis, termasuk partisipasi oleh pemerintah disponsori entitas. Secara umum bank syariah merupakan bank yang dalam kegiatannya dapat menawarkan beberapa produk secara langsung kepada masyarakat, yaitu produk yang berupa akad wadiah, mudharabah, musyarakah, murabahah, ijarah, wadiah, kafalah, dan hawalah (Sula, 2010).

Pada umumnya, produk-produk yang ditawarkan oleh perbankan syariah dapat dibagi menjadi tiga bagian yang utama (Karim, 2004:83): produk penyaluran dana (financing), produk penghimpunan dana (funding), dan produk jasa (service). Dalam menyalurkan dana kepada nasabah, secara garis besar produk perbankan syariah dapat dibagi menjadi beberapa skema sebagai berikut (Zulkifli, 2003:59). Skim Murabahah merupakan skim yang muncul karena bank tidak memiliki barang yang diinginkan oleh pembeli, sehingga bank harus melakukan transaksi pembelian atas barang yang diinginkan kepada pihak lainnya yang disebut supplier. Dengan demikian, dalam skim ini bank bertindak selaku penjual di satu sisi, dan di sisi lain bertindak sebagai pembeli. Kemudian bank akan menjualnya lagi kepada pembeli dengan harga yang telah disesuaikan yaitu harga beli bank dan margin keuntungan yang telah disepakati. Dengan kata lain, murabahah merupakan akad jual beli barang dengan menyatakan harga perolehan barang dengan marjin keuntungan yang telah h disepakati antara penjual dan pembeli. Skim musharakah mutanaqisah adalah suatu skim musharakah yang banyak berkembang sekarang ini dengan melakukan penyertaan modal secara terbatas dari suatu mitra usaha kepada perusahaan lain untuk suatu jangka waktu tertentu. Dalam dunia bisnis biasa skim ini banyak dikenal dengan nama modal ventura. Skim Bai al Istishna adalah skim pembiayaan atas dasar pesanan; untuk kasus saat objek atau barang yang diperjualbelikan belum ada. Skim Bai As salam adalah pembiayaan; pembeli diharuskan untuk membayar sejumlah uang tertentu untuk kemudian dilakukan pengiriman barang. Skim Musharakah merupakan skim pembiayaan; bank dan nasabah sama-sama memiliki kontribusi dana dalam usaha. Pengembalian hasil usaha tergantung kepada nisbah bagi hasil yang disepakati nasabah dan bank. Makin tinggi kinerja usaha nasabah, makin tinggi pula bagi hasil untuk masing masing pihak. Skim Bai wal Ijarah adalah skim bank membeli objek sewa dari supplier dan kemudian menyewakannya kepada pihak lain tanpa diikuti dengan perpindahan kepemilikan di akhir sewa. Skim ini banyak dipakai dalam rangka pemanfaaatan barang-barang yang menjadi asset yang dipergunakan untuk kegiatan produksi. Skim ijarah wal ijarah adalah kondisi ketika pihak bank menyewakan manfaat sewa atas aset yang bukan dimilikinya kepada pihak lain. Dalam kondisi ini yang diijarahkan adalah manfaat objek, bukan objek itu sendiri. Skim Ijarah Muntahiya Bi Tamlik Wal IBMT dengan hibah adalah kondisi ketika pihak bank melakukan penyewaan manfaat sewa atas aset yang bukan miliknya itu kepada pihak lain, dan diakhiri dengan perpindahan kepemilikan secara hibah pada akhir masa sewa menyewa. Skim Qard merupakan pinjaman tanpa meminta tambahan apapun, terkecuali biaya administrasi. Skim ini juga sering kali dikenal dengan nama pembiayaan berbasis qardhul Hassan atau pembiayaan berbasis kebajikan. 


\section{KPR Syariah}

Produk KPR merupakan produk yang dikeluarkan oleh kalangan perbankan dalam rangka membantu masyarakat memenuhi kebutuhan perumahan mereka. Keikutsertaan kalangan perbankan dalam membantu pengadaan perumahan bagi masyarakat sangat penting karena merupakan bagian dari program pemerintah untuk membantu pengadaan perumahan bagi masyarakat. Sedemikian pentingnya masalah perumahan tersebut membuat pemerintah bersama DPR telah mengeluarkan UU No 4 tahun 1992 yang menegaskan dalam Bab 1 Pasal 1: "rumah adalah bangunan yang berrfungsi sebagai tempat tinggal atau hunian dan sarana pembinaan keluarga."

Dalam dunia perbankan, produk ini biasa dinamakan dengan Kredit Pemilikan Rumah atau biasa dikenal dengan nama KPR. Dalam KPR yang biasa dijalankan oleh perbankan konvensional produk tersebut dapat dipastikan tidak akan lepas dari bunga yang merupakan ciri utama dari bank konvensional. Dalam KPR konvensional biasa terlibat berbagai unit-unit lain seperti pihak perseroan terbatas yang akan menyediakan lokasi yang dipergunakan dalam kegiatan pembangunan rumah. Selain itu juga terdapat hal lain yang terdapat dalam KPR konvensional diantaranya adalah harga jual yang bersifat kontan, uang muka dan suku bunga angsuran yang harus dibayarkan oleh nasabah serta berbagai barang dan juga keperluan lain yang harus dibayarkan oleh pihak debitur. KPR sendiri dibagi menjadi dua, yaitu KPR subsidi dan KPR non subsidi. Yang dimaksud dengan KPR subsidi adalah KPR yang diperuntukkan untuk masyarakat yang memiliki kemampuan ekonomi yang lemah. Sedangkan yang dimaksudkan dengan KPR non subsidi adalah KPR yang diperuntukkan bagi seluruh masyarakat tanpa adanya campur tangan dari pihak pemerintah.

Produk KPR yang ada pada perbankan syariah pada dasarnya berbeda dengan KPR yang ada di perbankan konvensional. Perbedaan ini dapat terjadi karena terdapat perbedaan prinsip antara perbankan syariah dengan perbankan konvensional. Dalam perbankan syariah biasa dikenal konsep berbasis bagi hasil dan juga perdagangan. Sedangkan dalam perbankan konvensional dikenal sistem yang berbasis bunga. Dalam produk yang biasa dikenal dengan nama KPR syariah ini terdapat beberapa karakteristik yang berbeda, di antaranya adalah tidak adanya pemberlakuan sistem kredit yang ada pada perbankan konvensional. Sementara pada perbankan syariah dikenal sistem murabahah yang berbasis margin, musyarakah mutanaqisah yang memiliki ciri khas partisipasi kepemilikan.

KPR syariah dapat juga menggunakan akad murabahah yang berbasis jual beli. Dalam kebiasaan yang ada pada perbankan syariah konsep murabahah merupakan konsep perdagangan berbasis jual beli yang pembayarannnya dilakukan secara tangguh atau cicilan. Dalam akad ini pihak bank syariah bertindak sebagai penjual yang akan melakukan penjualan aset kepada nasabahnya secara tangguh atau dengan cicilan. Dalam akad murabahah pihak bank syariah akan melakukan penjualan barang dagangan kepada para nasabahnya dengan keuntungan yang telah disepakati oleh kedua belah pihak. Akad KPR syariah yang menggunakan sistem murabahah membuat pihak bank syariah harus memberitahukan kepada pihak nasabahnya berkaitan dengan harga perolehan rumah yang diperoleh bank syariah dari pihak developer. Kemudian bank syariah dengan harga tersebut lalu menetapkan keuntungan yang akan diambilnya di mana margin keuntungan tersebut disepakati oleh kedua belah pihak.

Ketika bank umum syariah memutuskan menggunakan akad murabahah, maka terdapat beberapa hal yang harus dipenuhi oleh bank syariah tersebut, yaitu: (1) pihak yang berakad, terdiri dari pihak penjual dan pembeli; (2) objek yang diakadkan, terdiri dari barang yang dijadikan objek perdagangan dan juga harga jual barang yang disepakati akan dipakai; dari harga tersebut, maka dapat diperhitungkan keuntungan yang akan didapatkan; (3) akad harus terdiri dari ijab dan qabul dari kedua belah pihak. Berdasarkan konsep dari akad murabahah, maka terdapat beberapa hal yang harus dipenuhi dalam KPR syariah berbasis murabahah, yaitu: (a) pihak bank syariah harus memberitahukan akad yang digunakan dalam KPR syariah kepada para nasabahnya, (b) kontrak yang ada dalam transaksi KPR syariah harus dipastikan sah, (c) harus terdapat kejelasan akan transaksi yang dilakukan 
antara pihak bank syariah dengan nasabah berkaitan dengan objek barang yang menjadi transaksi antara nasabah dengan bank syariah, (d) bank syariah sebagai penjual harus menjelaskan semua hal berkaitan dengan aktivitas pembelian dan penjualan barang tersebut.

Masalah penentuan keuntungan juga menjadi salah satu hal yang penting berkaitan dengan transaksi murabahah. Hal ini dikarenakan bank syariah juga memegang peranan sebagai lembaga yang berfungsi sebagai lembaga intermediari, atau lembaga perantara dari pihak yang mengalami surplus dana kepada pihak yang mengalami defisit dana. Dengan adanya peranan seperti itu, maka tentunya diharapkan akan terdapat keuntungan produk KPR syariah yang merupakan produk yang dikeluarkan bagi nasabah yang memerlukan pembiayaan dari bank syariah untuk mendapatkan rumah. Keuntungan itu adalah margin keuntungan yang nilainya tetap selama masa perjanjian tersebut. Dengan margin keuntungan yang sifatnya tetap tersebut, maka besarnya cicilan yang harus dibayarkan oleh pihak nasabah kepada bank syariah tidak akan berubah dan juga tidak akan memberatkan nasabah. Hal inilah yang membedakan antara bank syariah dengan bank konvensional. Berdasarkan konsep KPR syariah, maka penentuan harga dan juga keuntungan yang ada di dalam KPR syariah harus memenuhi beberapa hal yang penting, yaitu: (a) keuntungan yang diminta oleh bank syariah dan juga harus diketahui secara jelas oleh nasabah; (b) harga jual bank yang merupakan harga beli bank ditambah dengan keuntungan yang diambil oleh bank; (c) harga jual yang tidak boleh berubah selama masa perjanjian; (d) sistem pembayaran yang telah disepakati bersama (Haris, 2007).

Penerapan KPR syariah, atau dengan bahasa lain biasa dikenal dengan Islamic home mortgage financing berjalan dengan baik di beberapa bank syariah yang ada di luar negeri, di antaranya adalah Al Manzil Islamic bank (Amerika Serikat), CAIR Minnesota (Amerika Serikat), La Riba (Amerika Serikat). Ketiga lembaga tersebut menggunakan kombinasi akad murabaha dan ijarah wa iqtina untuk akad KPR syariah yang dikeluarkan oleh 3 lembaga tersebut (Thomas, 2001)

\section{Pemasaran KPR Syariah}

Pemasaran yang dilakukan terhadap produk KPR Syariah pada dasarnya sama dengan yang dilakukan oleh pihak pemasaran yang ada di berbagai bank baik bank konvensional maupun bank syariah. Pemasaran yang dilakukan merupakan pemasaran yang sesuai dengan apa yang disampaikan dalam Kotler dan Armstrong (2002) yang menyatakan bahwa pemasaran merupakan suatu proses sosial dan manajerial yang terdapat di dalamnya individu ataupun kelompok. Pemasaran yang dilakukan oleh bank syariah dalam produk yang berkaitan dengan KPR syariah haruslah merupakan pemasaran yang pada akhirnya berhasil membentuk nasabah menjadi nasabah yang semakin loyal kepada bank syariah. Hal ini akan sangat tergantung dengan pemahaman yang dimiliki oleh para karyawan bank syariah terhadap produk KPR syariah.

\section{METODE}

Penelitian ini dilakukan dengan mempergunakan metode deskriptif dan pengamatan awal. Penelitian berusaha untuk mendapatkan data laporan keuangan 11 bank umum syariah yang ada di Indonesia. Sebelas bank umum syariah tersebut adalah PT Bank Syariah Muamalat Indonesia, PT Bank Syariah Mandiri, PT Bank Syariah Mega Indonesia, PT Bank Syariah BRI, PT Bank Syariah Bukopin, PT Bank Panin Syariah, PT Bank Victoria Syariah, PT BCA Syariah, PT Bank Jabar dan Banten Syariah, PT Bank Syariah BNI, PT Maybank Indonesia Syariah.

Selain itu, penelitian dilakukan dengan menyebarkan kuesioner kepada para pegawai yang ada di bank syariah, terutama para pegawai bagian pemasaran. Kuesioner tersebut telah disebarkan kepada beberapa bank syariah antara lain PT Bank Muamalat, PT Bank Jabar Banten Syariah, PT BPD Jogja Unit Usaha Syariah, PT BTN Unit Usaha Syariah, dan PT BNI Syariah. 


\section{HASIL DAN PEMBAHASAN}

Data yang terkumpul adalah sebagai berikut. Pertama, PT Bank Muamalat Indonesia merupakan bank syariah yang diketahui memiliki program KPR syariah dengan nama KPR Muamalat IB dengan menggunakan akad murabahah dan juga murabahah mutanaqisah. Kuesioner yang disebarkan berjumlah 40 dan kembali 30 kuesioner. Dari jawaban yang diperoleh terlihat bahwa 70\% dari karyawan yang ada di PT Bank Muamalat Indonesia belum dapat memberikan pemahaman yang seragam berkaitan dengan produk KPR Syariah. Sementara, kedua akad tersebut merupakan akad yang berbeda, sehingga bila pemahaman yang diberikan tidak seragam, dapat menyebabkan para calon nasabah bias dalam menerima informasi tentang KPR syariah.

Selain itu, penelitian awal ini menggunakan data yang diperoleh dari PT Bank Muamalat Tbk. Dalam data awal tersebut, PT Bank Muamalat memiliki produk berkaitan dengan KPR syariah yaitu KPR Muamalat IB. Seperti yang disampaikan dalam situs resmi PT Bank Muamalat dikatakan bahwa produk tersebut merupakan produk yang dikeluarkan oleh PT Bank Muamalat dengan tujuan untuk mendapatkan rumah, rumah toko, dan juga apartemen. KPR IB yang dikeluarkan oleh PT Bank Muamalat merupakan KPR dengan akad musyarakah mutanaqisah dan juga dengan akad murabahah. (Bank Muamalat, n.d.)

Berkaitan dengan KPR yang dikeluarkan oleh PT Bank Muamalat, penyebaran kuesioner telah dilakukan kepada para karyawan PT Bank Muamalat. Melalui pihak Muamalat Institite kuesioner tersebut kemudian dibagikan kepada 35 pihak karyawan bagian pemasaran dan juga back office di PT Bank Muamalat. Jumlah kuesioner yang kembali adalah sekitar 25. Adapun hasil dari kuesioner tersebut adalah sebagai berikut. Pertama, lebih dari mayoritas responden (90\%) menyatakan bahwa produk yang dikeluarkan oleh bank syariah bukan produk yang tertinggal dibandingkan dengan bank konvensional. Kedua, dari hasil yang diperoleh dapat dilihat bahwa banyak karyawan yang ada di PT Bank Muamalat mendapatkan informasi tentang produk KPR syariah yang dikeluarkan PT Bank Muamalat dari pihak internal perusahaan pada pelatihan tentang produk-produk KPR syariah yang mereka dapatkan. Meskipun begitu, 70\% dari menyatakan bahwa mereka memahami bahwa masih terdapat keluhan yang disampaikan oleh masyarakat berkaitan dengan produk KPR syariah yang dikeluarkan oleh Bank Muamalat. Ketiga, karyawan yang bekerja di bagian back office ataupun administrasi rata-rata merasa ragu dengan bagaimana KPR syariah tersebut dipasarkan di PT Bank Muamalat.

Data kedua yang terkumpul adalah PT BTN Syariah. Berbeda dengan data yang didapatkan melalui kuesioner, di PT BTN Syariah kuesioner yang diberikan dalam penelitian tidak mendapatkan respons yang semestinya. Akan tetapi, PT BTN Syariah memberikan data yang diharapkan dapat memberikan gambaran dan simpulan mengenai perkembangan KPR syariah yang dikeluarkan oleh perusahaan. Adapun datanya adalah seperti Tabel 1, Tabel 2, dan Tabel 3.

Tabel 1 Data KPR Bank BTN Syariah Tahun 2011 (Margin 8.2142\%)

\begin{tabular}{lcc}
\hline \multicolumn{1}{c}{ Bulan } & JumlahKonsumen & JumlahRealisasi \\
\hline Januari & 4 & $277,000,000$ \\
Februari & 14 & $3,832,000,000$ \\
Maret & 8 & $1,546,000,000$ \\
April & 13 & $2,172,000,000$ \\
Mei & 39 & $3,283,000,000$ \\
Juni & 33 & $3,227,000,000$ \\
Juli & 32 & $3,721,000,000$ \\
Agustus & 34 & $3,926,000,000$ \\
September & 21 & $1,608,000,000$ \\
Oktober & 25 & $3,601,000,000$ \\
November & 51 & $3,725,000,000$ \\
Desember & 35 & $3,874,000,000$ \\
Total & 309 & $34,792,000,000$ \\
\hline
\end{tabular}


Tabel 2 Data KPR Bank BTN Syariah Tahun 2012 (Margin 8.7142\%)

\begin{tabular}{lcr}
\hline \multicolumn{1}{c}{ Bulan } & JumlahKonsumen & JumlahRealisasi \\
\hline Januari & 7 & $1,148,000,000$ \\
Februari & 21 & $2,964,000,000$ \\
Maret & 31 & $3,564,000,000$ \\
April & 27 & $4,887,000,000$ \\
Mei & 3 & $414,000,000$ \\
Juni & 73 & $6,206,000,000$ \\
Juli & 27 & $4,679,000,000$ \\
Agustus & 32 & $3,880,000,000$ \\
September & 10 & $2,345,000,000$ \\
Oktober & 29 & $5,084,000,000$ \\
November & 15 & $2,814,000,000$ \\
Desember & 30 & $7,064,000,000$ \\
Total & 305 & $45,049,000,000$ \\
\hline
\end{tabular}

Tabel 3 Data KPR Bank BTN Syariah Tahun 2013 Margin 9.1132\%

\begin{tabular}{lcr}
\hline \multicolumn{1}{c}{ Bulan } & JumlahKonsumen & JumlahRealisasi \\
\hline Januari & 13 & $2,038,000,000$ \\
Februari & 33 & $5,416,000,000$ \\
Maret & 34 & $5,704,000,000$ \\
April & 34 & $10,336,000,000$ \\
Mei & 37 & $9,675,000,000$ \\
Juni & 46 & $9,703,000,000$ \\
Juli & 49 & $9,304,000,000$ \\
Agustus & 12 & $3,022,000,000$ \\
September & 29 & $5,879,000,000$ \\
Oktober & 18 & $4,219,000,000$ \\
November & 32 & $6,831,000,000$ \\
Desember & 38 & $10,151,000,000$ \\
Total & 375 & $82,278,000,000$ \\
\hline
\end{tabular}

\section{SIMPULAN}

Dari penelitian yang dilakukan dalam tahun ke-0 ini dapat dilihat bahwa KPR syariah merupakan salah satu instrumen pembiayaan yang banyak dilakukan oleh perbankan syariah. Berdasarkan data yang dikumpulkan, dapat dilihat bahwa dari 11 bank umum syariah yang ada di Indonesia 6 di antaranya memiliki pembiayaan untuk KPR syariah meskipun dengan jumlah yang fluktuatif. Berfluktuasinya KPR syariah yang dikeluarkan oleh perbankan syariah lebih banyak disebabkan pemahaman masyarakat yang belum benar tentang konsep KPR syariah tersebut.

Penelitian awal yang dilakukan di PT Bank Muamalat menunjukkan hasil bahwa perlu adanya pengembangan yang dilakukan agar produk KPR syariah dapat lebih mudah dipahami oleh para calon nasabah. Sementara dari data yang diperoleh mengenai perkembangan KPR syariah yang dmiliki oleh PT BTN syariah, dapat dilihat bahwa naik turunnya jumlah KPR syariah yang dapat direalisasikan menunjukkan bahwa KPR syariah di bank tersebut belum dapat dijadikan sebagai produk unggulan dari bank itu. Penelitian lanjutan perlu dilakukan dengan data yang lebih banyak, sehingga simpulan mengenai tingkat pemahaman KPR syariah ini bisa diperoleh secara lebih komprehensif. 


\section{DAFTAR PUSTAKA}

Aliah, W. (2010). Preferensi Nasabah terhadap Kredit Kepemilikan Rumah (KPR) Syariah: Studi pada BTN Syariah Cabang Bogor. Skripsi pada Fakultas Syariah \& Hukum. Jakarta: UIN Syarif Hidayatullah.

Alwi, M. (2011). Evaluasi Pemasaran Produk Kredit Pemilikan Rumah (KPR) Syaraih dengan Akad Murabahah (Studi Pada Bank Permata Cabang Kebun Jeruk Jakarta). Skripsi Tidak diterbitkan. Jakarta: UIN Syarif Hidayatullah.

Bank Muamalat. (n.d.). KPR Muamalat iB. Diakses dari http://www.bankmuamalat.co.id/produk/kprmuamalat-ib\#.VFGoI1c37kY

Haris, H. (2007). Pembiayaan kepemilikan rumah (sebuah inovasi pembiayaan perbankan syari'ah). La Riba: Jurnal Ekonomi Islam, 1(1), 113-125.

Karim, A. A. (2004). Bank Islam: Analisis Fiqih dan Keuangan. Jakarta: Raja Grafindo Persada.

Kotler, P. \& Armstrong, G. (2002). Dasar-dasar Pemasaran. Alih bahasa: Alexander Sindoro dan Benyamin Molan. Jakarta: Prenhalindo.

Meera, A. K. M. \& Razak, D. A. (2005). Islamic home financing through musharakah mutanaqisah and al-Bay’ bithaman ajil contracts: A comparative analysis. Review of Islamic Economics, 9(2), 5-30.

Rosyida, E. (2013). Analisa perbandingan pembiayaan hunian syariah dengan akad murabahah dan akad musyarakah pada Bank Muamalat (studi kasus pada Bank Muamalat Surabaya). Jurnal Akuntansi Unesa, 1(3). Diakses dari http://ejournal.unesa.ac.id/index.php/jurnal akuntansi/article/view/2305/baca-artikel

Sula, A. E. (2010). Reformulasi Akad Pembiayaan Murabahah Dengan Sistem Musyarakah Sebagai Inovasi Produk Perbankan Syariah. Makalah Dipresentasikan pada Simposium Nasional Akuntansi XIII, 2010.

Undang-Undang Republik Indonesia Nomor 4 Tahun 1992 tentang Perumahan dan Permukiman.

Zulkifli, S. (2003). Panduan Praktis Transaksi Perbankan Syariah. Jakarta: Zikrul Hakim. 